Paweł Hanczewski

Uniwersytet Mikołaja Kopernika, Toruń

ORCID: 0000-0003-4164-6310

e-mail: ph@umk.pl

\title{
Edmund Burke: natura czlowieka i rozum człowieka
}

Edmund Burke (1730-1797) i Oświecenie nie pasują do siebie. Takie stanowisko dominowało wśród uczonych przez długi czas. Burke’a łączono z „Kontroświeceniem”, opisywano jako „filozofa nieracjonalności $\mathrm{w}$ wielkim wieku rozumu" (a philosopher of unreason in the great age of Reason $)^{1}$. Burke przyczyniał się do tych ocen, pisząc: „Nie nawróciliśmy się na Rousseau, nie jesteśmy uczniami Voltaire'a", a zarazem krytykując „filozofię tego oświeconego wieku” oraz „rzekomych filozofów obecnej doby"2. Poglądy badaczy wynikały z przyjęcia koncepcji Oświecenia jako negacji "starego ładu" ucieleśnianego przez monarchię absolutna, rządy arystokracji oraz zinstytucjonalizowaną religię, pełną prymitywnych wierzeń, ograniczającą swobodę myślenia i równocześnie Oświecenia rozumianego jako afirmacja sekularyzmu, humanitaryzmu, kosmopolityzmu i wolności od ucisku, a także wolności do swobodnego

${ }^{1}$ Isaiah Berlin, Pod prad. Eseje z historii idei, red. Henry Hardy (Poznań: Zysk i S-ka, 2002), 81; Alfred Cobban, Edmund Burke and the revolt against the eighteenth century: a study of the political and social thinking of Burke, Wordsworth, Coleridge and Southey (London: George Allen \& Unwin, 1962 [pierwsze wydanie 1929]), 75; Peter Gay, The Enlightenment. An Interpretation, t. 1: The Rise of Modern Paganism (New York: Knopf, 1966), XI-XIII. Najlepszego przeglądu opinii badaczy na temat Burke'a i Oświecenia dokonał Jonathan Charles Douglas Clark, patrz: tenże, „The Enlightenment, Religion and Edmund Burke", Studies in Burke and His Time 21 (2007): 9-38.

2 Edmund Burke, Rozważania o rewolucji we Francji, przeł. Dorota Lachowska (Kraków: Społeczny Instytut Wydawniczy Znak, 1994), 102-103, 154, 173. 
rozwoju jednostki w społeczeństwie ${ }^{3}$. Burke'a znacznie chętniej łączono z romantyzmem, szczególnie niemieckim, na który miał wywrzeć duży wpływ, dostarczając teoretycznego uzasadnienia dla "buntu wobec współczesnego świata" (a revolt against modern world) ${ }^{4}$. Zmiana poglądów wielu badaczy na temat Oświecenia, która nastąpiła w ciągu ostatnich dekad, kazała podać w wątpliwość powyższe oceny, a tak wybitny badacz jak Jonathan Israel określił Burke’a mianem ,jednego z dwóch [obok Hume'a] największych myślicieli Oświecenia" - choć nie radykalnego Oświecenia, z którym Burke pozostawał w ostrym sporze ${ }^{5}$. Także rozwój badań nad spuścizną intelektualną Burke'a kazał zrewidować poglądy. Przez prawie dwa stulecia jego dorobek przedstawiano w kontekście bieżącej walki politycznej. W XIX wieku przyznawali się do niego zarówno liberałowie, dla których był jednym z ideowych ojców założycieli klasycznego państwa liberalnego, jak i konserwatyści, dla których był twórcą doktryny konserwatyzmu brytyjskiego ${ }^{6}$. Po drugiej wojnie światowej widziano go jako proroka ostrzegającego przed zagrożeniami ze strony ideologii totalitarnych bądź też jako zwolennika starego porządku, zagradzającego drogę postępowi ${ }^{7}$. Istniała jednak grupa badaczy, która podkreślała, że w ciągu trwającej ponad czterdzieści lat kariery pisarskiej i politycznej Burke zmieniał poglądy, co dało podstawę do twierdzeń, że było dwóch Burke'ów: wczesny i liberalny oraz późny i konserwatywny ${ }^{8}$. Jednak od połowy lat osiemdziesiątych i prac Johna Pococka9', związanego z tak zwaną szkołą kontekstualizmu historycznego z Cambridge, której celem jest analiza dorobku wybitnych myślicieli w kontekście lingwistycznym, historycznym i społecznym,

3 Gay, The Enlightenment, 3.

4 Encyclopedia of the Enlightenment, vol. 1, ed. Michel Delon (Chicago: Fitzroy Dearborn Publishers, 2001), 336-337; Richard Bourke, „Burke, Enlightenment and Romanticism", w: The Cambridge Companion to Edmund Burke, ed. David Dwan, Christopher J. Insole (Cambridge: Cambridge University Press, 2012), 34-37.

${ }^{5}$ Jonathan Irvine Israel, Democratic Enlightenment: Philosophy, Revolution, and Human Rights 1750-1790 (Oxford: Oxford University Press, 2011), 4, 6, 16, 941; John Greville Agard Pocock, „Historiography and Enlightenment: A View of Their History”, Modern Intellectual History 5, 1 (2008): 83-85.

${ }^{6}$ Emily Jones, Edmund Burke and the Invention of Modern Conservatism, 1830-1914: An Intellectual History (Oxford: Oxford University Press, 2017).

7 Crawford Brough Macpherson, Burke (Oxford: Oxford University Press, 1980), $5-6,71-73$.

8 Conor Cruise O'Brien, The Great Melody. A thematic biography and commented anthology of Edmund Burke (London: Sinclair-Stevenson, 1992), 602. Podobne stanowisko w odniesieniu do poglądów na temat roli arystokracji i porządku społecznego zajmuje Israel, Democratic Enlightenment, 29-30.

9 John Greville Agard Pocock, "Josiah Tucker on Burke, Locke, and Price. A study in the varietes of eighteenth-century conservatism", w: tenże, Virtue, Commerce, and History (Cambridge: Cambridge University Press, 1985), 158-159. 
zanegowano wszystkie te poglądy. Burke w trakcie całej działalności publicznej z uznaniem wyrażał się o zmianach politycznych, społecznych i kulturowych, które miał szansę obserwować ${ }^{10}$, a jego atak na rewolucję we Francji nie był skierowany przeciwko Oświeceniu. Z punktu widzenia Burke'a stanowił obronę Oświecenia przed zagrożeniami ze strony „atawistycznych, moralnych, intelektualnych i politycznych występków"11, które - w najlepszym razie - groziły cofnięciem Francji i Europy do epoki wojen religijnych. Burke miał własną koncepcję Oświecenia, które polegało na stopniowym „rozwoju społeczeństwa dzięki ekspansji handlu pod opieką prawa, rozwoju moralnym pod okiem Opatrzności i złagodzeniu religii pod wpływem nauki"12.

Jednym z głównych źródeł koncepcji Oświecenia przyjętej przez Burke’a były jego poglądy na temat ludzkiego rozumu i ludzkiej natury. Pisał o nich już w latach młodzieńczych, podczas studiów w Trinity College w Dublinie ${ }^{13}$. Burke nie rościł sobie jednak pretensji do miana filozofa i nawet jego jedyna praca, w tytule której znalazło się odniesienie do filozofii, Dociekania filozoficzne o pochodzeniu naszych idei wzniosłości i piękna z 1757 roku, była w opinii współczesnych, między innymi Immanuela Kanta, zaledwie wstępem do właściwych rozważań filozoficznych ${ }^{14}$. Burke nie podjął próby zdefiniowania pojęć „,rozum człowieka” i „natura człowieka", podkreślał natomiast zagrożenia wynikające z oderwania rozumu od natury. Takie uwagi pojawiły się już w Obronie społeczeństwa naturalnego z 1756 roku, pierwszej pracy, która zapewniła mu uznanie w kręgach intelektualnych i politycznych. Przestrzegał w niej przed „nadużywaniem rozsądku” ${ }^{15}$ (Reason), dokonał też rozróżnienia na „rozum naturalny" i „rozum nienaturalny" (natural reason i artificial reason). Znacznie wyżej oceniał ten drugi, ponieważ łączył on rozum naturalny z ludzką wiedzą i doświadczeniem ${ }^{16}$. Przemyślenia na temat związków między rozumem i naturą ludzką pojawiały się też w jego późniejszych

${ }_{10}$ Richard Bourke, Empire E Revolution. The Political Life of Edmund Burke (Princeton: Princeton University Press, 2015), 68-70, 374-375.

${ }_{11}$ Jonathan Charles Douglas Clark, „Introduction”, w: Edmund Burke, Reflections on the Revolution in France, ed. Jonathan Charles Douglas Clark (Stanford: Stanford University Press, 2001), 89; Bourke, Empire E Revolution, 688.

${ }^{12}$ Bourke, „Burke, Enlightenment and Romanticism”, 27.

${ }^{13}$ Ian Crowe, Patriotism and Public Spirit. Edmund Burke and the Role of the Critic in Mid-Eighteenth-Century (Stanford: Stanford University Press, 2012), 118-151; Bourke, Empire \& Revolution, 68.

${ }_{14}$ Paddy Bullard, „Burke's Aesthetic Psychology”, w: The Cambridge Companion to Edmund Burke, ed. David Dwan, Christopher J. Insole (Cambridge: Cambridge University Press, 2012), 53.

${ }^{15}$ Edmund Burke, "Obrona społeczeństwa naturalnego", w: tenże, O duchu i naturze rewolucji. Wybór pism, przeł. Agnieszka Wincewicz-Price (Kraków: Ośrodek Myśli Politycznej, 2012), 6.

16 Tamże, 37, 47, 49. 
wystąpieniach. Moim celem jest przedstawienie poglądów Burke'a w tej kwestii, zawartych w jego najbardziej znanym dziele, Rozważaniach o rewolucji we Francji. Pomijając to, że zapewniły one Burke'owi intelektualną i polityczną nieśmiertelność, są najczęściej wykorzystywane jako argument na rzecz tezy, że Burke znajdował się w opozycji wobec Oświecenia. $\mathrm{W}$ bliskich nam czasach takie stanowisko zajęła między innymi Gertrude Himmelfarb, uczona łączona z postawą konserwatywną która podkreślała nieufny stosunek Burke'a do rozumu ${ }^{17}$. Odpowiedź na pytanie, w jaki sposób Burke przedstawił w Rozważaniach związki między naturą człowieka i jego rozumem, pozwolą zrewidować to stanowisko.

Rozważania ukazały się w końcowym etapie działalności publicznej Burke'a, 1 listopada 1790 roku, i powstały w odpowiedzi na wydarzenia we Francji oraz na ich przyjęcie w niektórych kręgach intelektualnych i politycznych Wielkiej Brytanii. Dotykają one głównie zagadnień o charakterze politycznym, ale towarzyszą im rozważania na temat ludzkiego rozumu i natury, zgodnie z poglądem powtarzanym przez Burke'a w trakcie jego całej kariery publicznej, że istnieje ścisły związek między nimi a światem polityki ${ }^{18}$. W Rozważaniach pisał: „przez całe życie starałem się poznać naturę ludzką; inaczej nie byłbym zdolny do odegrania nawet mojej skromnej roli w służbie ludzkości"19. W Rozważaniach łatwo znaleźć sformułowania potwierdzające tezę, że Burke bardzo nieufnie podchodził do rozumu człowieka. Krytykował „nagi rozum", ,teorie praw człowieka”, ,"mechanistyczną filozofię”, ,"specjalistów od intelektualnych spekulacji" ${ }^{20}$. Jednocześnie pozytywnie wyrażał się o "ludzkiej naturze”, „,naturze człowieka”, ,postępowaniu zgodnym z naturą", „ideach pochodzących ze skarbca moralnej wrażliwości”, "uczuciach wewnętrznych"21. Aby jednak zrozumieć sens tych sformułowań, należy je rozpatrywać w kontekście całości poglądów Burke’a.

Analizując jego życie i dorobek intelektualny, uczeni próbują określić, które zagadnienia uważał za najbardziej istotne. Poza oczywistym dążeniem do oddzielenia spraw ważnych i mało ważnych, w grę wchodzi spór o to, czy istniał związek między poglądami Burke'a z wczesnego i późnego okresu. We wspomnianej już i bardzo dobrze przyjętej biografii Burke'a, napisanej przez Richarda Bourke'a, umieszczono tytuł Empire and Revolution, wskazując, że kluczowymi zagadnieniami były kwestie związane z imperium brytyjskim - Irlandia, kolonie w Ameryce

17 Gertrude Himmelfarb, Drogi do nowoczesności: brytyjskie, francuskie i amerykańskie Oświecenie, przeł. Kinga Wudarska (Warszawa: Fundacja Świętego Mikołaja. Redakcja „Teologii Politycznej”, 2018), 114.

18 George McElroy, „Edmund Burke and the Scottish Enlightenment”, Man and Nature/L'homme et la nature 11 (1992): 171-185.

19 Burke, Rozważania, 151.

20 Tamże, 75, 79, 82, 95, 104.

21 Tamże, 52, 78, 82, 94, 106. 
Północnej, Indie oraz zagrożenia dla stabilności państwa wynikające albo z rywalizacji na szczytach władzy między politykami i stronnictwami (to w przypadku Wielkiej Brytanii), albo z rewolucji (to we Francji). Tym zagadnieniom towarzyszyło pytanie, w jaki sposób zapewnić sprawne rządy $\mathrm{w}$ wielkim zamorskim imperium i w poszczególnych państwach europejskich. Odpowiedź, bez względu na to, czy chodziło o najważniejsze, czy o najmniej istotne zagadnienia, była zawsze ta sama. Właściwy sposób sprawowania władzy to znalezienie równowagi między wolnością i porządkiem. Taki stan Burke określał jako „wolność całującą porządek” bądź, mniej górnolotnie, jako połączenie wolności i porządku: „Ale wolność, jedyna wolność, o jakiej mówię, powiązana jest z porządkiem"22. W osiągnięciu i utrzymaniu równowagi Burke widział podstawowy warunek dla prawidłowego funkcjonowania państw i społeczeństw. Pisał o niej w odniesieniu do współczesnej Wielkiej Brytanii, chwaląc ją za "zrównoważoną konstytucję" (ballanced constitution). Pisał o niej w odniesieniu do Rzeczpospolitej, pokazując na jej przykładzie, jak naruszenie równowagi, najpierw w sferze religijnej, a następnie politycznej, czyli „doskonała wolność” szlachty, było w rzeczywistości formą niewoli, doprowadziło do upadku potężnego niegdyś państwa. Stan równowagi okazał się niezbędny także w przypadku systemu europejskiego. Jak wielu współczesnych ${ }^{23}$, Burke stawiał pytanie o sposób utrzymania pokoju, a odpowiedź znajdował w koncepcji równowagi sił. Przywiązywał do niej wielkie znaczenie; był to jeden z najważniejszych elementów, które zapewniły państwom europejskim przewagę nad pozostałymi częściami świata. Brakowi równowagi przypisał z kolei upadek kwitnących niegdyś ośrodków polityki, gospodarki i kultury w Azji ${ }^{24}$. W Rozważaniach obecne jest również podobne rozumowanie, tyle że dotyczące spraw polityki. Jeden z najpoważniejszych zarzutów, jakie stawiał rewolucjonistom, był taki, że świadomie zanegowali sens równowagi, wybierając skrajne rozwiązania: „Uznają jedynie wojny i rewolucje; wszystko albo nic" ${ }^{\prime 25}$. W zamian proponował umiar: „Lecz w tej sprawie [kształtu systemu politycznego i społecznego], podobnie jak we wszystkich sprawach państwa, istnieje złoty środek. Między alternatywą: absolutna destrukcja lub brak reform jest coś jeszcze"26.

${ }^{22}$ Edmund Burke, „Przemówienie po przybyciu do Bristolu”, w: tenże, Odwołanie od nowych do starych wigów. Wybór pism, przeł. Agnieszka Wincewicz-Price (Kraków: Ośrodek Myśli Politycznej, 2015), 113.

${ }^{23}$ Matthew Smith Anderson, The Rise of Modern Diplomacy 1450-1919 (London: Longman, 1993), 163-180.

24 The Annual Register, or a View of the History, Politics, and Literature, For the Year $1772,2$.

25 Burke, Rozważania, 81.

26 Tamże, 170. 
Myślenie w kategoriach równowagi można odnieść także do poglądów na temat rozumu i jego związków z naturą ludzką. Krytyka „nagiego rozumu” czy „mechanistycznej filozofii” nie musi przecież oznaczać odrzucenia rozumu. Może wynikać z rozczarowania tym, w jaki sposób został on wykorzystany. W Rozważaniach znajdziemy szereg uwag wskazujących, że Burke doceniał znaczenie rozumu. Pisał o „ponadczasowym rozumie”, „rozumie ludzkości [który] zbudował... dostojną strukturę państwa”, konieczności trzymania się „horyzontu rozumu”, a wreszcie o „kreatywnej mocy ludzkiego rozumu” ${ }^{27}$. Rozum mógł zatem pełnić ważną i pozytywną funkcję. We Francji jednak odegrał rolę jednoznacznie negatywną prowadząc do ruiny państwa i społeczeństwa. Stało się tak dlatego, że rewolucjoniści oddzielili rozum od tego, co Burke ukrył pod terminem "okoliczności”, które „czynią dany obywatelski i polityczny system dobroczynnym lub zgubnym dla rodzaju ludzkiego" ${ }^{\prime 28}$. Przez „okoliczności”, które miały niewiele wspólnego z aktualnymi wydarzeniami, rozumiał historię, religię, kulturę, obyczaje, przesądy, prawa i często bardzo trudno dostrzegalne związki między nimi. Rozum zastępował „okoliczności” teoriami, próbując kierować społeczeństwem za ich pomocą. Skutki były opłakane. Rozum ludzki okazał się „omylny i słaby" 29 i choćby z tego względu nie można było traktować go jako jedynego narzędzia władzy. Słabość rozumu potęgował fakt, że człowiek to niezwykle skomplikowana istota: „Natura człowieka jest zawikłana, elementy społeczeństwa w najwyższym stopniu złożone, dlatego żadna prosta strategia czy orientacja... nie może odpowiadać ani naturze człowieka, ani charakterowi jego spraw" ${ }^{\prime \prime 30}$. Podobnie jak wolność doprowadzona do skrajnej postaci stanowiła formę niewoli, tak rozum, który nie brał pod uwagę "okoliczności”, był swoim zaprzeczeniem. W imię „rozumu”, w czasie krótszym niż półtora roku, w najpotężniejszej monarchii europejskiej zburzono ład polityczny, społeczny, gospodarczy i kulturowy, który budowano przez stulecia ${ }^{31}$. W zamian nie zaproponowano nic nowego i trwałego. Rewolucjoniści robili to samo, w sensie negatywnym, co wcześniejsze pokolenia, od których tak bardzo chcieli się odseparować. Na płaszczyźnie intelektualnej stworzyli „dogmaty filozofów"32, które przypominały „zabobony mnichów” z tą jednak różnica, że „zabobony mnichów” służyły niedoskonałej, niemniej budowie,

27 Tamże, 39, 108, 157, 171.

28 Tamże, 27.

29 Tamże, 53.

30 Tamże, 79.

31 Edmund Burke to Earl of Fitzwilliam-12 November 1789, w: The Correspondence of Edmund Burke, volume VI July 1789-December 1791, ed. Alfred Cobban and Robert A. Smith (Cambridge: Cambridge University Press, 1967), 36.

32 Burke, Rozważania, 105. 
natomiast "obecne zabobony” zmierzały wyłącznie do destrukcji ${ }^{33}$. W dziedzinach politycznej, społecznej i gospodarczej zastąpili stare instytucje nowymi, ale to nie wyeliminowało problemów, ponieważ te znajdowały źródło nie $\mathrm{w}$ „religii, obyczajach, prawach, prerogatywach, przywilejach, swobodach", lecz w ludzkich wadach, takich jak: „duma, ambicja, skąpstwo, zemsta, żądza, bunty, hipokryzja, fanatyzm" ${ }^{34}$. Stare instytucje przynajmniej brały tego typu cechy pod uwagę i nawet jeśli nie umiały ich wyeliminować, to przynajmniej łagodziły ich skutki. W przypadku natury ludzkiej rewolucjoniści także nie zaproponowali niczego konstruktywnego i trwałego. W ich oczach natura ludzka stanowiła wytwór warunków zewnętrznych. $W$ rezultacie była podatna na bezustanne zmiany, co chcieli wykorzystać, dążąc do jej przekształcenia. Zdaniem Burke'a pierwszym krokiem rewolucjonistów w tym kierunku była walka ze zinstytucjonalizowaną religią. Ośmieszenie Kościoła i wiary miało prowadzić do ukształtowania człowieka, który odrzucając religię, miał zostać poddany edukacji „o fizjologicznych potrzebach”, prowadzącej do utożsamienia interesu jednostkowego z interesem ogółu. To skutkowałoby utratą cech indywidualnych i stanowiłoby śmiertelne zagrożenie dla państwa i społeczeństwa ${ }^{35}$. Nie mogły one bowiem funkcjonować wyłącznie w oparciu o zasady prawa i związki gospodarcze. Pozbawiony stałych wartości, niezbędnych ze względu na niezmienny charakter natury człowieka, mógł istnieć tylko naród złożony $\mathrm{z}$ „prostackich, głupich, dzikich, a zarazem biednych i plugawych barbarzyńców, wyzbytych wiary, honoru, męskiej dumy, niemających nic i niespodziewających się niczego w przyszłości"36.

Nieszczęść można było zdaniem Burke’a uniknąć, gdyby rozumu nie oddzielono od ludzkiej natury, przy czym zależność ta działała w obydwie strony. Pozytywne opinie Burke'a na temat natury ludzkiej, szczególnie na tle krytycznych uwag dotyczących rozumu, nie powinny być odczytywane jako jej afirmacja. Burke nie miał wielkich złudzeń co do ludzkiej natury. To właśnie wspomniane słabości były podstawowym źródłem nieszczęść, a jednak za najlepszy sposób postępowania uznał tolerancję: „Muszę znosić ludzkie słabości dopóty, dopóki nie wyradzają się one $\mathrm{w}$ zbrodnie" ${ }^{\prime \prime 3}$. Ludzie często kierowali się emocjami, a ich cechą charakterystyczną było dążenie do despotyzmu, rozumianego nie tyle $\mathrm{w}$ kategoriach politycznych, co jako pragnienie poniżenia innych ludzi ${ }^{38}$. Rozum okazał się niezbędny, aby kontrolować te słabości i dopiero takie

\footnotetext{
33 Tamże, 173.

34 Tamże, 155.

35 Tamże, 162.

36 Tamże, 96.

37 Tamże, 158.

38 Tamże, 121, 153.
} 
połączenie stanowiło podstawę do właściwej egzystencji jednostek, społeczeństw i państw. Jak ujął to Burke, wzniosłe idee, które mają „,pokryć defekty naszej nagiej, ułomnej duszy i nadać jej godność [...] pochodzące ze skarbca moralnej wrażliwości [są] zadomowione w sercu, lecz aprobowane przez rozum" ${ }^{39}$. Efektem był "rozum praktyczny”, który stanowił jednak więcej niż sumę tylko dwóch elementów. Jego trzeci, równie istotny składnik stanowiła „praktyczna mądrość” ${ }^{40}$, którą można było nabyć dzięki korzystaniu z wiedzy pokoleń i, w mniejszym stopniu, dzięki własnemu doświadczeniu. Znaczenie tego, co w innym miejscu nazwał „mądrością prostaków" ${ }^{41}$, wynikało z przekonania o ograniczeniach rozumu, a także koncepcji państwa oraz społeczeństwa jako sztafety pokoleń. Rządzący i rządzeni powinni korzystać z doświadczenia poprzedników i przekazywać swoje doświadczenia następcom. Gdyby tego nie uczynili, zostałaby zerwana więź międzypokoleniowa i w konsekwencji ludzie nie różniliby się od „roju much”"42. Jednak głównym powodem tego, że „rozum praktyczny” nie mógł istnieć bez doświadczenia zbieranego przez kolejne generacje, było to, że wiedza o tworzeniu i reformowaniu państw miała praktyczny charakter i służyła praktycznym celom $^{43}$. Ten praktyczny charakter i cele poznawało się przez doświadczenie.

Rozum oderwany od ludzkiej natury i doświadczenia nie znał ograniczeń, ale tylko w dziele zniszczenia. Obiecując wspaniałą przyszłość, nie mógł zaproponować nic nowego i trwałego. Pod pozorem nowości i światowości był wyrazem dążenia do niczym nieograniczonej władzy i powrotem do czasów barbarzyńskich ${ }^{44}$. Prowadził też do degradacji moralnej ludzi. Nie tylko negował istniejącą moralność, ale też świadomie wykorzystywał najciemniejsze zakamarki ludzkich serc: „Wyciągnęliście korzyści z wielu skłonności i namiętności ludzkiego ducha, które z punktu widzenia moralności są równie wątpliwe jak zabobony"45. W imię „udoskonalonego państwa ludzkiego rozumu” przyjęto, że cel uświęca środki, czyniąc ogół obywateli wspólnikami przestępstwa ${ }^{46}$ i otwierając drzwi do kolejnych zbrodni: „tolerowanie zbrodniczych środków prowadzi rychło do ich preferowania [...]. Usprawiedliwianie perfidii i morderstw popełnianych dla dobra ogółu prowadzi wprost do

\footnotetext{
39 Tamże, 94.

40 Tamże, 51.

41 Tamże, 75.

42 Tamże, 111.

43 Tamże, 78.

44 Tamże, 126-127.

45 Tamże, 172.

46 Tamże, 137.
} 
sytuacji, w której dobro to staje się pretekstem, a perfidia i morderstwo celem" ${ }^{\prime 4}$.

Rozum połączony z naturą ludzką oraz doświadczeniem pokoleń napotykał ograniczenia właśnie tam, gdzie „czysty” rozum ich nie znał w dziele niszczenia. Służył bowiem ulepszaniu już istniejącego gmachu cywilizacji, nie jego destrukcji: „Skłonność do zachowywania i zdolność ulepszania wzięte razem - oto mój wzór męża stanu"48. Jednak dzięki temu przyczyniał się do stopniowego rozwoju państw i społeczeństw. Przyczyniał się też do stopniowego doskonalenia natury ludzkiej. Zdaniem Burke'a człowiek miał pochodzący od Boga dar „stwarzania samego siebie”, ale mógł to czynić tylko poprzez wykorzystanie „instytucji moralnych, obywatelskich i politycznych" ${ }^{\prime 9}$. Była to znacznie mniej efektowna wizja niż ta promowana przez rewolucjonistów, którzy obiecywali wyzwolenie z pęt przeszłości i kultury, ale jedyna, jeśli człowiek nie miał stać się niewolnikiem swych namiętności i tych, którzy będą sprawowali władzę. Bo, jak pisał Burke: „Jak aś władza musi istnieć w społeczeństwie, w czyichś rękach, pod jakąś nazwą"50. To właśnie w odmiennych poglądach na temat związków między naturą człowie$\mathrm{ka}$, rozumem i doświadczeniem, nie w odrzuceniu rozumu, widziałbym jedno z najważniejszych źródeł, obok poglądu, że rewolucjoniści negują podstawowe założenia prawa naturalnego ${ }^{51}$, bardzo krytycznej oceny rewolucji dokonanej przez Burke'a. Problem polegał na tym, że rewolucjoniści uznali, iż człowieka można i należy dopasować do teoretycznych założeń, a poprzez oddzielenie go od „okoliczności” ukształtować od nowa. Burke nie chciał „nowego człowieka”, chciał, aby człowiek, korzystając z rozumu, znajomości swej natury, doświadczenia i mądrości zgromadzonej przez pokolenia, stopniowo łagodził swe postępowanie. Na tle Voltaire'a czy Denisa Diderota, nie mówiąc już o przedstawicielach radykalnego Oświecenia, Burke zajmował umiarkowane stanowisko. Czy jest to wystarczająca podstawa do twierdzeń o wrogim stosunku Burke’a do Oświecenia i wykluczenia go z grona Oświeconych?

Akceptuję pogląd profesora Quentina Skinnera, który stwierdza, że wybitni myśliciele przeszłości nie dostarczają nam sposobów na rozwiązywanie naszych problemów. Nie akceptuję jednak poglądu, że $\mathrm{w}$ historii idei nie ma wiecznych problemów i pytań, są tylko indywidualne pytania i indywidualne odpowiedzi, właściwe dla konkretnych

47 Tamże, 98-99.

48 Tamże, 171.

49 Tamże, 109.

50 Tamże, 103, 155.

51 Peter J. Stanlis, Edmund Burke and the Natural Law (Lafayette: Huntington House, 1986 [pierwsze wydanie 1958]), 75. 
społeczeństw i czasów ${ }^{52}$. Pytania o związek między ludzkim rozumem, ludzką naturą i ludzkim doświadczeniem zawarte w Rozważaniach o rewolucji we Francji pozostają aktualne zarówno na poziomie jednostek, jak i całych społeczeństw.

\section{Bibliografia}

Anderson Matthew Smith. 1993. The Rise of Modern Diplomacy 1450-1919. London: Longman.

Berlin Isaiah. 2002. Pod prad. Eseje z historii idei, red. Henry Hardy. Poznań: Zysk i S-ka.

Bourke Richard. 2012. „Burke, Enlightenment and Romanticism”. W: The Cambridge Companion to Edmund Burke, ed. David Dwan, Christopher J. Insole, 27-40. Cambridge: Cambridge University Press.

Bourke Richard. 2015. Empire \& Revolution. The Political Life of Edmund Burke. Princeton: Princeton University Press.

Bullard Paddy. 2012. „Burke's Aesthetic Psychology”. W: The Cambridge Companion to Edmund Burke, ed. David Dwan, Christopher J. Insole, 53-66. Cambridge: Cambridge University Press.

Burke Edmund. 1994. Rozważania o rewolucji we Francji, przeł. Dorota Lachowska. Kraków: Społeczny Instytut Wydawniczy Znak.

Burke Edmund. 2012. „Obrona społeczeństwa naturalnego”. W: Edmund Burke, O duchu i naturze rewolucji. Wybór pism, przeł. Agnieszka Wincewicz-Price, 1-66. Kraków: Ośrodek Myśli Politycznej.

Burke Edmund. 2015. Przemówienie po przybyciu do Bristolu. W: Edmund Burke, Odwołanie od nowych do starych wigów. Wybór pism, przeł. Agnieszka Wincewicz-Price, 111-114. Kraków: Ośrodek Myśli Politycznej.

Clark Jonathan Charles Douglas. 2001. „Introduction”. W: Edmund Burke Reflections on the Revolution in France, ed. Jonathan Charles Douglas Clark, 17-111. Stanford: Stanford University Press.

Clark Jonathan Charles Douglas. 2007. „The Enlightenment, Religion and Edmund Burke". Studies in Burke and His Time 2: 9-38.

Cobban Alfred. 1962. Edmund Burke and the revolt against the eighteenth century: a study of the political and social thinking of Burke, Wordsworth, Coleridge and Southey. London: George Allen \& Unwin.

Crowe Ian. 2012. Patriotism and Public Spirit. Edmund Burke and the Role of the Critic in Mid-Eighteenth-Century. Stanford: Stanford University Press.

Encyclopedia of the Enlightenment, vol. I. 2001. Ed. Michel Delon. Chicago: Fitzroy Dearborn Publishers.

Gay Peter. 1966. The Enlightenment. An Interpretation, vol. 1: The Rise of Modern Paganism. New York: Knopf.

52 Quentin Skinner, „Znaczenie i rozumienie w historii idei”, przeł. Filip Biały, Refleksje 9 (2014): 162-163. 
Himmelfarb Gertrude. 2018. Drogi do nowoczesności: brytyjskie, francuskie i amerykańskie Oświecenie, przeł. Kinga Wudarska. Warszawa: Fundacja Świętego Mikołaja. Redakcja „Teologii Politycznej”.

Israel Jonathan Irvine. 2011. Democratic Enlightenment: Philosophy, Revolution, and Human Rights 1750-1790. Oxford: Oxford University Press.

Jones Emily. 2017. Edmund Burke and the Invention of Modern Conservatism, 1830-1914: An Intellectual History. Oxford: Oxford University Press.

Macpherson Crawford Brough. 1980. Burke. Oxford: Oxford University Press.

McElroy George. 1992. „Edmund Burke and the Scottish Enlightenment”. Man and Nature/L'homme et la nature 11: 171-185.

O'Brien Conor Cruise. 1992. The Great Melody. A thematic biography and commented anthology of Edmund Burke. London: Sinclair-Stevenson.

Pocock John Greville Agard. 1985. „Josiah Tucker on Burke, Locke, and Price. A study in the varietes of eighteenth-century conservatism". W: John Greville Agard Pocock, Virtue, Commerce, and History, 157-191. Cambridge: Cambridge University Press.

Pocock John Greville Agard. 2008. „Historiography and Enlightenment: A View of Their History". Modern Intellectual History 5, 1: 83-96.

Skinner Quentin. 2014. „Znaczenie i rozumienie w historii idei”, przeł. Filip Biały. Refleksje 9: 127-163.

Stanlis Peter J. 1986. Edmund Burke and the Natural Law. Lafayette: Huntington House.

The Annual Register, or a View of the History, Politics, and Literature, For the Year 1772.

The Correspondence of Edmund Burke, volume VI July 1789-December 1791. 1967. Ed. Alfred Cobban and Robert A. Smith. Cambridge: Cambridge University Press.

\section{Streszczenie}

Przez długi czas badacze przedstawiali Edmunda Burke’a jako przeciwnika Oświecenia, wskazując między innymi na jego nieufny stosunek do ludzkiego rozumu. Celem niniejszego artykułu jest analiza poglądów Burke'a na temat relacji między naturą człowieka i jego rozumem, zawartych $\mathrm{w}$ jego najbardziej znanej pracy pt. Rozważania o rewolucji we Francji. Taka analiza umożliwi nie tylko poznanie wspomnianych poglądów, ale będzie stanowiła również element $\mathrm{w}$ dyskusji na temat stosunku filozofa do Oświecenia.

Słowa kluczowe: Edmund Burke, Oświecenie, natura człowieka, rozum człowieka 


\section{Edmund Burke: Human Nature and Human Reason}

\section{Summary}

For a long time, scholars have presented Edmund Burke as an enemy of the Enlightenment, stressing, inter alia, his skepticism towards human reason. This article analyzes Burke's views concerning the relationship between human nature and human reason as described in his best-known work, Reflections on the Revolution in France. This will not only allow us to consider his opinions in this field but also to better understand his stance towards the Enlightenment.

Keywords: Edmund Burke, Enlightenment, human nature, human reason 